\title{
Internal Marketing- A Tool to Harness Employees’ Power in Service Organizations in India
}

\author{
Sita Mishra \\ Institute of Management Technology \\ Rajnagar, Ghaziabad, India \\ E-mail: smishra@imt.edu
}

\begin{abstract}
Customer service is one of the most crucial aspects of an organization's competitive advantage and it is the critical element which internal marketing (IM) influences, whatever business or industry the organization operates. Internal marketing is based on the notion of communicating with internal markets and treating employees like customers. Implementing an internal marketing plan helps in educating, stimulating, guiding and leading workforce to higher levels of performance and gratification. The service employee often represents the organization in the eyes of the customer. Due to this, the role of employee is both complex and multi-dimensional. The internal customer concept is a promising area of study in the marketing and organizational behaviour literature. This study contributes to the understanding of what IM is and focuses on importance of employees in service encounters. Further, the paper focuses on rationale for adoption of this concept within services organizations in India.
\end{abstract}

Keywords: Internal marketing, Service encounters, Service industry, Internal customer

\section{Introduction}

Employees are the backbone of any business success and therefore, they need to be educated, motivated and maintained in organization at all cost to support the organization to be globally competitive. In service organizations, frontline employees are critical to the success of the organizations as they are in direct contact with external customers. Accordingly, these employees can have an elevated impact on the quality of products and services delivered by the firm and this influence should be fully leveraged by supervision (Hartline and Ferrell, 1996). The increasing recognition of the importance of the employees' role in the service industry has led service organizations to adopt Internal Marketing (IM) and hence, treat their employees as internal customers. The approach basically inverts the organizational pyramid and puts customers on top and divides the employees into two categories, viz., (i) those who serve customers and (ii) those who serve those serving the external customers. Hence, the front-line employees became internal customers to the back-office support service staff, supervisors and management. Internal marketing is emerging as a central theme of increasing importance in both academic and practitioner discourse. Snell (2009) indicated that internal marketing is practiced within professional services, albeit with varying degrees of sophistication, in order to execute wide ranging projects related to marketing and human resources. Internal marketing can refurbish the face of a company (George 1990), as has been reported by case studies and anecdotal accounts indicating clear gains in employee understanding of corporate values, employee commitment, service quality, customer satisfaction, and loyalty (Opoku et al, 2009; Sartain 2005; Ahmed and Rafiq 2002; Bergstrom, Blumenthal, and Crothers 2002; Hallam 2003).

The objective of internal marketing is to get motivated and customer conscious employees in order to achieve service excellence. Motivated employees are crucial to a company's success, this has never been truer than today, when margins are thin and economic recovery remains elusive. According to Fisk et al. (1993) there are two main issues in internal marketing. Firstly, the idea of the employee as the internal customer and secondly, the organizational need to satisfy the internal customer so that $\mathrm{s} / \mathrm{he}$ is best prepared to serve the external customer. Although external marketing remains the most important business development task, it is essential to sell inwardly toward a company's people. When employees understand and commit to the value proposition of the company, external marketing becomes more effective, because the employees become product campaigners. The internal market of employees is best motivated for service-mindedness and customer oriented behavior by active, marketing approach, where a variety of activities are used internally in an active, marketing-like and coordinated way.

Internal marketing is a means of involving staff at all levels in effective marketing programmes by enabling them to understand their role within the marketing process. Internal marketing programmes consist of training and staff development, effective internal communications and integration schemes, de-signed to enhance knowledge and 
understanding of the overall marketing orientation within the organization. Internal marketing encompasses a number of elements, all of which help contribute towards enhanced customer service and a greater degree of marketing orientation within the organization. Service orientation has become a key source of competitive advantage and only a 'service attitude' among staff can lead to the delivery of outstanding customer service and increased market share (Varey and Lewis 1999). The internal marketing concept has been developed largely within the context of services marketing; however, internal marketing is now becoming more and more important to all organizations striving for marketing success.

\section{Research Methodology and Objectives}

Service sector is the largest and fastest growing sector, globally contributing more to the global output and employing more people than any other sector. As the Indian economy is growing, there is significant development happening in various service sectors viz. retailing, banking, BPO, ITES, health, education, hospitality etc. Despite the growth in the overall employee base, companies in service sectors are struggling to retain their existing employees. Analysts observed that managing attrition in the industry is one of the pertinent issues because high attrition rate not only affects the quality of service and also leads to higher training and development expenditure, affecting the overall performance of the organization. For any organization, employee behavior as a touch point with customers is exceptionally important and a negative experience will cost an organization more than just the opportunity of doing business with an individual.

The framework presented in this paper integrates and synthesizes conceptualizations of Internal marketing from the marketing, services and organizational behaviour literature to aid practitioners to understand the dimensions of HR challenges in services industry and examine how internal marketing will help HR practitioners to improve their HR skills and employee performance.

The specific objectives of this paper are:

1. To analyse HR challenges in service industry globally and specific issues to Indian service industry

2. To understand role of employee in service encounter

3. To review and provide a critique on the literature on internal marketing and its impact on organization

4. To provide rationale behind adopting internal marketing and identifying areas where IM can play a vital role

\section{HR challenges in Service Industry}

The phenomenal expansion of the Services Sector worldwide has led to services being considered as one of the most important sectors contributing to world gross domestic product. In developed countries, more people are employed in the services sector than in agriculture or industry, unlike the developing countries. Managing talent in service industry is the most critical HR challenge worldwide and will remain at or near the top of executive agendas in every region for the foreseeable future. The ability to gain competitive advantage through people strategies requires an overall HR approach.

According to Hillmer et al. (2004) fast changing work environments, combined with how service operations are managed, often lead to high stress which can result in increasing employee turnover. Besides this, service organizations are more labour intensive than manufacturing organizations therefore employees have become critical success factor in service companies (Normann, 2000). It is important that they are taken care of so that it can result in lower employee turnover, economic growth and satisfied customers. Czaplewski et al (2001) mentioned that while nearly every service company says its goal is to provide excellent service, evidence shows that the service quality of many organizations is below customer expectations. One of the basic reasons for service quality problems is the lack of commitment and skills of the frontline employees who are interacting with customers.

In last two decades with growing Indian economy, a significant development took place in various service sectors. Regardless of growth and opportunities in this sector it also faces several HR issues which are a key challenge for the industry in India. One of the main problems for service organizations has been attracting and retaining high quality employees (Heskett et al., 2008). An analysis of secondary sources (mainly articles from newspapers and business magazines and the very few available research papers on Indian service sector) reveal problems that can seriously impact the high growth rates predicted for this sector. These include issues such as increasing employee turnover, stressful work environment and poor career development (Singh, 2005, Grossman, 2006). In addition, finding and retaining talented people, training, and career planning are pertinent areas which need to be addressed. Service organizations interface with customers through various touch points and these touch points are not secluded but immediate and inter-connected. Globally, there has been increasing attention to the personal interaction between the customer and the employee on the frontline of service businesses (Mattson, 1994). Employees who are happy in their place of work are more motivated to contribute and can do so more effectively. This also translates into better consumer experiences and in turn, leads to stronger financial performance by the firm and overall economic growth.

In India there is an increasing demand and supply gap for professionals. It is sometimes difficult for HR managers to maintain consistency in performance and keep the motivation levels high especially when the work is monotonous. Despite the large number of students graduating every year, there is now an increasing scarcity of appropriate skills 
gained through the education system, which is low on quality and relevance. Because of shortages, the hiring of new talent has become more expensive.

Employee attrition represents significant costs to service industry companies. High attrition rates drive up training costs, and increase human resources, recruiting, and productivity costs. They also increase the prospect of customer service complaints or quality problems, and create substantial continuity problems for longer-lived projects. Because of high turnover, companies are required to hire more aggressively, resulting in a gradual loss of the basic cost-effective. model of Indian service industry. In India, the average annual attrition rate in the business process outsourcing (BPO) sector hit a high of close to $50 \%$ a few years ago. Better attrition management and the 2008-2009 global economic slowdown have helped reduce the figure to $24-30 \%$, but this still has a significant impact on costs and quality (Mike, 2009). The hospitality industry suffers from a high-attrition rate at almost all levels. Whether hiring people at entry level or in senior management roles, there are many challenges (Jauhari and Manaktola, 2009). This increases the costs of hiring and training employees. Therefore, being a people intensive sector, service industry companies need to pay special attention to the internal marketing activities. They must attract, retain and keep employees motivated and committed at all times (Deery and Kinnie, 2004), which, in turn, ensures delivery of high quality service to customers (Schneider and Bowen, 1995). Employees are the strength of any business success since their value to the organization is essentially intangible and not easily replicated Meaghan et al. (2002) therefore; managers in various organizations must ensure that there is employee continuity in their organizations to enhance organizational competitiveness. Dunmore (2002, p. 5) advocated that internal marketing is increasingly important to organizations due to growth in significance of the service sector and the knowledge-based economy.

\section{Role of the Employees in Service Encounter}

In service organizations employees are vital part of the services offered to customers and hence, there is a need to ensure that they can proficiently deliver the promises made to customers in all service delivery encounters. In literature, service encounters are also labeled as moments of truth. Contact employees have undoubtedly one of the most difficult yet rewarding jobs in the service organizations. Since the service employee works on the boundary of the organization and performs boundary spanning roles (Friedman and Podolny, 1992), the organization has high stakes on how the service employee behaves in service encounters. These service employees are faced with multiple challenges on a daily basis ranging from technical faults to badly behaved customers. It is the manner in which these challenges are dealt with and the degree to which one can cope with the strain of boundary spanning roles, which distinguishes excellent service providers. The boundary spanning role has been defined as activity which links an organization with the environment within which it operates (Bateson and Hoffman, 1999, p.62). It is the task of people in boundary spanning roles to create these links by communicating with those in the outside environment. Those operating in a boundary spanning capacity must be motivated to fulfill two tasks information transfer and representation. Singh et al. (1994) stated that personnel who are operating in boundary spanning roles are prone to high levels of emotional burnout and role conflict.

While interacting with the service, the customer comes not only in to contact with the contact personnel but also with the physical facilities, the other customers and other visible elements. In these cases, customer perceptions of service quality are affected by the physical environment as well as by the behavior of the relevant service personnel (Zeithaml et al 2006). Regardless of whether contact points are visible or not, they constitute moments of truth - points in time during which customers are afforded the opportunity to gauge service quality. If multiple touch points are involved in performing a job function, it may very well be feasible to remove some contact points while still performing the function. Each touch point provides the customer an occasion to gauge the performance of an organization; leaving in unnecessary touch points increases the probability of an unpleasant evaluation (Spence \& Kale, 2008).

From an Internal Marketing perspective, many researchers have argued that by satisfying the needs of their internal customers, firms enhance their ability to satisfy the needs of their external customers. However, both customers and employees need to be seen as part of a virtuous circle in which attention given to one reinforces attention given to the other. George (1990) illustrated that relational exchanges between employees within an organization should be considered a prerequisite for successful exchanges with external markets. The satisfaction of the internal customer is of critical importance as satisfaction will ultimately effect the satisfaction of the external market (Ballantyne, 1997, Heskett et al., 2008). Therefore, good organizations carefully manage employee-customer interactions to mitigate the possibility of an unfavourable encounter which could ruin the overall experience. Contact personnel in the service encounter have an opportunity to customise the service delivered to each customer. Customisation of the service encounter adds value to the customer's experience of the service and also contributes to the creation of a sustainable competitive advantage (Lewis and Entwistle, 1990).

\section{Concept of Internal Marketing}

Berry et al. (1976) were probably the first ones who proposed internal marketing as a way out to the problem of delivering consistently high quality of service. They developed the idea that because people were the most common form of service delivery, their actions probably had a major impact on customer acquisition, retention and migration, 
and thus the definitive success of the firm. Gronroos (1981) proposed that each customer facing employee be trained as marketer that would enable the building of customer relationships. The remaining employees of the organization should support these customer-facing employees. It was emphasized that the focus of the organization was not only providing an excellent experience, but based on developing an ongoing relationship with the customer which would result into additional sales and profits. The major thrust of the internal marketing concept is that by treating employees as internal customers, one can ensure higher employee satisfaction and, subsequently, the development of a more customer-conscious, market-oriented, and sales-minded work force (Gronroos 1981).

Kotler (1991) defined internal marketing as .the task of successfully hiring, training and motivating able employees to serve the customer well. In this respect it represents elements of good human resources management (HRM) (Bateson, 1991). Rafiq and Ahmed (2000) developed a hybrid approach and proposed that internal marketing was inherently difficult to implement because of inter-functional conflicts and therefore the focus was on overcoming organizational inertia by identifying the specific behavioural changes employees needed to make. Internal marketing was defined as a planned effort using marketing like approach to overcome organizational resistance, to change and to align, motivate, and inter-functionally co-ordinate and integrate employees towards the effective implementation of corporate and functional strategies in order to deliver customer satisfaction through the process of creating motivated and customer-orientated employees. Internal marketing focuses on people inside organizational boundaries and places emphasis on the satisfaction of employee needs (Ahmed and Rafiq, 2003). Davis (2001) suggested that internal marketing can bridge the gap between the different internal constituencies and establishing cooperation among them. In a similar vein, Ballantyne (2003) mentioned that internal marketing is a relationship development strategy. Nowadays the concept is being increasingly discussed in the literature as a strategic tool for meeting and exceeding customers' expectations (Lings 2004; Papasolomou-Doukakis 2002; Mudie 2003). Consequently, IM can be seen as a way of managing the exchanges among organizational members that are required to achieve a high level of service for the external customers. Increased awareness of employee importance in organizational change and implementation has contributed to the adoption of internal marketing (Gronroos, 1994; Papasolomou, 2006; Varey and Lewis, 1999).

\section{Literature Review on Internal Marketing and Its Effect on Organizations}

The rationale for the adoption of Internal Marketing is to ensure that employees feel that management cares about them and their needs are met. The successful application of the concept is transformed into positive employee attitudes towards their work including organizational commitment, job involvement, work motivation and job satisfaction (Tansuhaj et al, 1991). De Brum (1998) emphasized that the foremost objective of internal marketing is to assure that all employees are informed about the firms' vision, i.e. their management initiatives, goals, outcomes, services, products and served markets. However, Vasconcelos (2004) highlighted internal marketing as a vital mechanism in which one can build work environments where employees can find and enjoy unique job experiences as well as they are fostered to achieve their full potential.

One of the important outcomes of internal marketing is to increase the organizational commitment of employees (Tansuhaj et al., 1991). This in turn should result in increased job satisfaction; increased job performance and lower turnover of staff (Jenkins and Thomlinson, 1992; Mathieu and Zajac, 1990; Schlessenger and Haskett, 1991) thus help the interactive process. Caruana and Calleya (1998) also examined internal processes associated with delivering customer satisfaction focusing particularly on the relationship between the nature and extent of internal marketing and its outcome in terms of the level of organizational commitment on the part of employees. The findings confirm a significant relationship between internal marketing and organizational commitment. The relationship of internal marketing is most significant with the affective dimension of organizational commitment. There is some empirical support for a significant relationship between internal marketing and service quality (Yafang Tsai, 2008; Opoku, 2009) and between internal marketing and business performance (Panigyrakis, 2009).

The objective of internal marketing is to create an internal environment in which customer consciousness propagates among personnel. The satisfaction of internal customers is important to the success of a service firm (Gremler et al., 1994).The ability of organizations to develop and gain a competitive advantage through an emphasis on service quality is substantively influenced by the organizational culture. A number of researchers also relate enhanced organizational performance with a strong organizational culture (Barney 1986; Saffold 1988) and improved employee productivity (Deal and Kennedy 1982; Schein 1985). Internal marketing is believed to contribute towards achieving organizational goals (Gilmore, 2003).

Organizations that select, develop, manage and motivate their workforce to produce outstanding business results have an extraordinary competitive advantage that others can not copy (Nalbantian et al., 2004). Hogg (1996) has suggested that internal marketing could be the answer to gaining employee commitment, succeeding where traditional internal communications programmes have failed. Lack of commitment from employees can be harmful to an organization, resulting in poorer performance arising from inferior service offerings and higher costs. Drake et al. (2005) suggested that the effective implementation of marketing techniques internally can create significant bottom-line results. Drake et 
al. (2005) asserted that by engaging in a carefully planned internal marketing plan the corporation can convert employees into company fanatics who will generate financial rewards. Similarly, Dunmore (2002) posited that a strong internal marketing strategy can be critical to achieving and sustaining competitive advantage, as well as being a key driver of change and enhanced performance. The successful implementation of internal marketing can lead to: improved employee retention, stronger individual performance, better teamwork, and more effective overall communications (Drake et al., 2005). Empirical results demonstrate that a significant relationship exists between internal marketing and consumer satisfaction and between internal marketing and service quality (Bansal et al., 2001; Ewing and Caruana, 1999).

\section{Rationale for the Adoption of Internal Marketing}

It is clear, therefore, that internal marketing is concerned with more than treating the employee as a customer; it signifies that the organization should constantly endeavour to develop programmes and strategies for enhancing employee satisfaction in much the same way as external marketing plans which are continuously updated and improved to meet external customer demands. Internal marketing is becoming increasingly important and growing recognition as an implementation tool for adoption by all organizations. Prasad and Steffes (2002) mentioned that internal marketing must precede external marketing, if not the organization may offer a service it is unable to provide. From the organizational perspective, the need of the hour is a well-structured and rationalised internal marketing approach that can significantly improve employee relations with management and overall organizational competitiveness and performance. Only then can these organizations hope to respond to the challenges presented by globalization (Budhwar,2009). There are a number of areas where internal marketing can play a vital role:

Management of change: Many companies are undergoing some form of transformation through mergers, alliances, or downsizing. The need for communication is stronger in these circumstances. Moreover, constant organizational change can loosen the ties between employer and employee. Internal marketing can bring the parties together with shared goals and values. Internal marketing may be used to place, and gain acceptance of new systems such as the introduction of information technology and new working practices, and other changes. It creates good coordination and cooperation among departments of the business.

Building corporate image: When companies change their brand, their name, or their values, it is essential to communicate the change to all stakeholders including employees. Internal marketing can play a key role in creating awareness and appreciation of the company's aims and strengths - as all employees are potential company ambassadors. It integrates business culture, structure, human resources management, vision and strategy with the employees' professional and social needs.

Employee empowerment: Internal marketing empowers employees and gives them accountability and responsibility. Zeithaml and Bitner (1996) stipulated that many organizations accept that in order to be responsive to customer needs, front-line staff need to be empowered to accommodate customer requests, and to recover on the spot when things go wrong. As companies empower staff to build stronger customer relationship, internal marketing underpins the drive for greater involvement, commitment, and understanding.

\section{Enhancing Organizational Commitment}

Lack of commitment from employees can be harmful to an organization, resulting in poorer performance arising from inferior service offerings and higher costs. The major thrust of the internal marketing concept is to ensure that employees feel that management cares about them and their needs are met. If these are not met then the satisfaction of external customers is difficult, if they are met then employees become committed, co-operative, and enthusiastic about the organization (Ahmed et al., 2002; Ballantyne, 2003). Internal marketing encourages employees to offer superb service to customers by appreciating their valuable contribution to the success of the business. Hogg (1996) has suggested that internal marketing could be the answer to gaining employee commitment, succeeding where traditional internal communications programmes have failed. Caruana and Calleya (1998) also confirmed a significant relationship between internal marketing and organizational commitment.

Employee satisfaction: In service environments in which customers are highly demanding of employees, coupled with employees who in turn hold high expectations from their jobs as sources of self-actualization and self-development. Under these conditions, internal marketing approach can assist in creating more satisfied customer-contact employees who appreciate clearly the logic and benefit of courteous, empathetic behavior when dealing with customers, lead to greater customer satisfaction. Internal marketing which aims at reducing interdepartmental and inter-functional conflict and developing the co-operation and commitment needed to make external marketing strategies work.

Several researchers have criticized this concept of internal marketing and advocated that through internal marketing marketers are trying to extend their influence throughout the organization. Critics of internal marketing argued that the term is simply a synonym for good human resources management. However, internal marketing and human resource effectiveness are distinct and the former represents the antecedent of the latter (Ewing and Caruana, 1999). Gilmore and 
Carson (1995) criticized the dependence on techniques and concepts, designed for the implementation of external marketing programmes that may be inappropriate for internal markets. Rust et al. (1996) postulated that there is an overemphasis on the importance of frontline personnel, which can potentially create conflict and discontent among other staff members. Rafiq and Ahmed (1993) mentioned that internal marketing is highly incompatible in striving to meet both the requirements of internal and external customers simultaneously. Hales (1994) is very critical of the application of internal marketing to HRM. He argues that internal marketing is unable to provide a solid conceptual base emphasising, among others, the point that while HRM focuses on teamwork; internal marketing stresses individualism. Later, Ahmed and Rafiq (2004) criticised the concept of .employee as customer. Since it raises the question of whether the needs of external customers have predominance over those of employees.

\section{Conclusion}

In the service industry, human resources are the only assets that need to be nurtured generously. Many organizations corroborate that their employees are their most valuable resource. Keeping talent within organization is now becoming a central goal for HR professionals. Organizations provide freedom to their employees to perform by attaching them to a right job profile according to their preference and they are constantly encouraged to grow up the ladder through regular trainings. The training should be focused on what the employees are expected to achieve. Along with the motivation, they should also be equipped with enough tools to help themselves on their way. Customers often base their perceptions of the service on the quality of the interaction with service personnel. Service industry organizations now recognize the importance of quality and attempt to exceed the expectations of customers. For this reason it is essential that the employee is motivated to consistently deliver a high quality service experience to the customer. Motivation is especially important when employees operate in a boundary spanning position, as this involves high levels of stress and burn out.

In this paper internal marketing is proposed as a mechanism for ensuring the motivation of service employees. The implementation of an internal marketing program ensures that motivation is at the forefront of managements' priorities and is not solely the responsibility of human resources but must be adopted by all managers throughout the organization. It is believed organizational problems are internal, not external and therefore, implementation of an internal marketing program creates the opportunity to improve quality throughout the organization (Prasad \& Steffes, 2002). It can be concluded that internal marketing is a tool that harnesses the employee power and creates an environment where every member acts as both a client and customer in order to create responsibility.

\section{References}

Ahmed, P., and Rafiq, M. (2002). Internal Marketing: Tools and Concepts for Customer-focused Management. Butterworth-Heinemann, Oxford.

Ahmed, P. K., and Rafiq, M. (2003). Internal marketing issues and challenges. European Journal of Marketing, Vol. 37 No. 9, pp. 1177-86.

Ahmed, P. K., and Rafiq, M. (2004). Internal Marketing: Tools and Concepts for Customer Focused Management. Butterworth-Heinemann, Oxford.

Ballantyne, D. (2003). A relationship-mediated theory of internal marketing. European Journal of Marketing, Vol 37, No. 9, pp. 1242-1260.

Bansal, H. S., Mendelson, M.B., and Sharma, B. (2001) .The impact of internal marketing activities on external marketing outcomes. Journal of Quality Management, Vol. 6, pp. 61-76.

Barney, J. B. (1986).Organizational culture: can it be a source of sustained competitive advantage?. Academy of Management Review, Vol 11, No. 3, pp. 656-665.

Bateson, J. E. G., and Hoffman, K. D. (1996). Managing Services Marketing, 4th edn. Dryden Press, Dryden. U.S.A

Bergstrom, A., Blumenthal, D., and Crothers, S. (2002) .Why Internal Branding Matters: The Case of Saab. Corporate Reputation Review, 5 (2-3), 133-42.

Budhwar, P. S., Verma, A., Malhotra, N., and Mukherjee, A.(2009). Insights into the Indian call centre industry: can internal marketing help tackle high employee turnover? Journal of Services Marketing, Vol 23, No. 5, pp. 351-362

Caruana, A., and Calleya, P. (1998). The effect of internal marketing on organizational commitment among retail bank managers. The International Journal of Bank Marketing, Vol. 16 No. 3, pp. 108-16.

Czaplewski, A., Ferguson, J., and Milliman, J. (2001). Southwest airlines: How internal marketing pilots success. Marketing Management, Vol. 10 (3), pp 14-17

Davis, T. R. V. (2001). Integrating internal marketing with participative management. Management Decision, Vol 39, No. 1, pp. 121-132.

de Brum, A. M. (1998), Endomarketing como estrate'gia de gestã o, L\&PM, Porto Alegre, RS. 
Deery, S., Kinnie, N. (2004). Introduction: the nature and management of call centre work. in Deery, S., Kinnie, N. (Eds),Call Centres and Human Resource Management: A Cross-national Perspective, Palgrave Macmillan, Basingstoke, pp.1-22.

Drake, S. M., Gulman, M. J., and Roberts, S. M. (2005). Light Their Fire: Using Internal Marketing to Ignite Employee Performance and Wow Your Customers. Dearborn Trade, Chicago, IL.

Dunmore, M. (2002). Inside-out Marketing: How to Create an Internal Marketing Strategy. Kogan Page, London.

Ewing, M., and Caruana, A. (1999). An internal marketing approach to public sector management. The marketing and human resources interface. The International Journal of Public Sector Management, Vol. 12. No. 1, pp. 17-26.

Fisk, R. P., Brown, S. W., and Bitner, M. J. (1993). Tracking the Evolution of the Services Marketing Literature. Journal of Retailing, Vol. 69 No. 1, pp.61-103.

Friedman, R. A., and Podolny, J. (1992). Differentiation of boundary spanning roles: labor negotiations and implications for role conflict. Administrative Science Quarterly, Vol. 37, pp.28-47.

George, W. (1990). Internal marketing and organizational behavior: a partnership in developing customer-conscious employees at every level. Journal of Business Research, Vol. 10, pp. 63-70.

Gilmore, A. (2003). Services, Marketing and Management. Sage, London.

Gilmore, A., and Carson, D. (1995). Managing and marketing to internal customers. In: Glynn, W.J. and Barnes, J.G, (eds.), Understanding Services Management, Chichester: John Wiley and Sons, pp. 295-321.

Gremler, W. E., Bitner, M. J., and Evans, K. R. (1994). The internal service encounter. International Journal of Service Industry Management, Vol. 5, No. 2, pp. 34-56.

Gro"nroos, C. (1981). Internal marketing: an integral part of marketing theory. in Donnelly, J.H. and George, W.R. (Eds), Marketing of Services, Proceedings of the American Marketing Association, Services Marketing Conference, Chicago, IL, pp. 236-8.

Gronroos, C. (1994). From marketing mix to relationship marketing: Towards a paradigm shift in marketing. Management Decision, Vol. 32, No. 2, pp. 4-20.

Grossman, R. J. (2006). HR's rising star in India: in the hottest sectors of India's booming economy. HR Magazine, [Online] Available: http://findarticles.com/p/articles/mi_m3495/is_9_51/ai_n26993579/

Hales, C. (1994). Internal marketing as an application to human resources management. Human Resources Management Journal, Vol. 5, No. 1, pp. 50-71.

Hallam, R. (2003). Delivering the Brand Promise at Washington Mutual. Strategic Communication Management, Vol. 7 , No.4, 18-21.

Hartline, M. D., and Ferrell, O. C. (1996). The Management of Customer-contact service Employees: An Empirical Investigation. Journal of marketing, Vol.60, No.4, pp.52-70.

Heskett, J. L., Jones, T. O., Loveman, G. W., Sasser, W. E. Jr, Schlesinger, L. A. (2008). Putting the service-profit chain to work. Harvard Business Review, July-August, pp.118-29.

Hillmer, S., Hillmer, B., and McRoberts, G. (2004). The real costs of turnover: lessons from a call center. Human Resource Planning, Vol. 27 (3), pp 34-41

Hogg, C. (1996) .Selling your soul. Human Resources, Vol. 96 No. 25, pp. 88-90.

Jauhari, V., and Manaktola, K. (2009). Managing workforce issues in the hospitality industry in India. Worldwide Hospitality and Tourism Themes, Vol. 1, No. 1, pp: 19-24

Jenkins, M., and Thomlinson, P. P. (1992). Organizational commitment and job satisfaction as predictors of employee turnover intentions. Management Research News, Vol. 15, No. 10, pp. 18-22.

Kotler, P. (1991). Marketing Management - Analysis, Planning, Implementation and Control. $7^{\text {th }}$ ed., Prentice Hall, Englewood Cliffs, NJ.

Lewis, B. R., and Entwistle, T. W. (1990). Managing the service encounter: a focus on the employee. International Journal of Services Industry Management, Vol. 1, No. 3, pp.41-52

Lings, I. (2004). Internal Market Orientation: construct and consequences. Journal of Business Research, Vol 57, pp. 405-413.

Mathieu, J. E., and Zajac, D. M. (1990). A review and meta-analysis of the antecedents, correlates and consequences of organizational commitment. Psychological Bulletin, Vol. 108, No. 2, pp. 171-94. 
Mattson, J. (1994). Improving service quality in person-to-person encounters. The Service Industries Journal, Vol. 14, No.1, pp. 45-61

Meaghan Stovel., \& Nick Bontis. (2002). Voluntary turnover: knowledge management-friend or foe? Journal of intellectual Capital, Vol. 3 (3), pp 303-322

Mike. (2009). Employee Attrition in India. Online [Available]:

http://www.offshoreadvisor.com/resources/employee-attrition-in-india/

Mudie, P. (2003). Internal customer: by design or default. European Journal of Marketing, Vol. 37, No. 9, pp. 1261-1276.

Nalbantian, H. R., Guzzo, R. A., Kieffer, D., and Doherty, J. (2004). Play to Your Strengths: Managing Your Internal Labour Markets for Lasting Competitive Advantage. McGraw-Hill, New York, NY.

Normann, R. (2000). Service Management. Malmo: Liber AB.

Opoku, R. A., Nana A. Y., Chong, C. S., and Russell, A. (2009). The impact of internal marketing on the perception of service quality in retail banking: A Ghanaian case. Journal of Financial Services Marketing, Vol. 13, No. 4, pp. $317-329$

Panigyrakis, G. (2009). Internal marketing impact on business performance in a retail context. International Journal of Retail \& Distribution Management, Vol. 37, Issue 7, pp 600-628

Papasolomou, D. I. (2002).The role of employee development in customer relations: the case of UK retail banks. Corporate Communications: An International Journal, Vol. 7, No. 1, pp. 62-76.

Papasolomou, D. I. (2006). Can internal marketing be implemented within bureaucratic organizations?. International Journal of Bank Marketing, Vol. 24, No. 3, pp. 194-212.

Prasad, A., and Steffes, E. (2002).Internal marketing at Continental Airlines: Convincing employees that management knows best. Marketing Letters, Vol. 13(2), pp.75-89

Rafiq, M., and Ahmed, P.K. (1993). The scope of internal marketing strategy: defining the boundary between marketing and human resource management. Journal of Marketing Management, Vol. 9, No. 3, pp. 219-32.

Rafiq, M., and Ahmed, P.K. (2000). Advances in the internal marketing concept: definition, synthesis, and extension. Journal of Services Marketing, Vol 14, No. 6, pp. 449-462.

Rust, R. T., Zahorik, A. J., and Keiningham, T. L. (1996). Services Marketing. HarperCollins, New York, NY, .

Saffold, G. (1988). Culture traits, strengths and organizational performance: moving beyond strong culture. Academy of Management Review, Vol. 13 No.4, pp.546-58.

Sartain, L. (2005). Branding from the Inside Out at Yahoo!HR's Role as Brand Builder. Human Resource Management, 44 (1), 89-93.

Schlessenger, L. A., and Heskett, J. L. (1991). Breaking the cycle of failure in services. Sloan Management Review, Vol. 32 No. 3,pp. 17-28.

Schneider, B., and Bowen, D. E. (1995). Winning the Service Game. Harvard Business School Press, Cambridge, MA, .

Singh, J., Goolsby, J. R., and Rhoades, G. K. (1994). Behavioural and psychological consequences of boundary spanning burnout for customer service representatives. Journal of Marketing, Vol.31, November, pp.558-69

Singh, P., and Pandey, A. (2005) .Women in call centres. Economic and Political Weekly, Vol. 12 February.

Snell, L. (2009). An Exploratory Study of the Application of Internal Marketing in Professional Service Organizations. Services Marketing Quarterly, Vol. 30 Issue 3, pp 195-211

Spence, M. T., and Kale, S. H.(2008). Optimising the internal value chain: Principles and practices. Journal of management and organization, Vol 14, No.2, pp.193-206.

Tansuhaj, P., Randall, D., and McCullough, J. (1991). Applying the internal marketing concept within large organizations: as applied to a Credit Union. Journal of Professional Services Marketing, Vol. 6 No. 2, pp. 193-202.

Varey, R. J., and Lewis, B. R. (1999). A broadened conception of internal marketing. European Journal of Marketing, Vol. 33 Nos 9/10, pp. 926-44.

Vasconcelos, A. F. (2004). Processos de trocas intra-organizacionais: atualizando o conceito de marketing interno. Caderno de Pesquisa em Administrac, ã o, Vol. 11 No. 1, pp. 37-50.

Yafang Tsai., and Ta-Wei Tang. (2008). How to improve service quality: Internal marketing as a determining factor. Total Quality Management \& Business Excellence. Abingdon, Vol. 19, Iss. 11, pg. 1117. 
Zeithaml V. A, Bitner M. J., and Gremler D. D. (2006). Services Marketing: Integrating Customer Focus Across the Firm. (4th edn) McGraw-Hill Irwin, NY.

Zeithaml, V. A., and Bitner, M. J. (1996). Services Marketing. McGraw-Hill, Singapore. 